\title{
Urine neutrophil gelatinase-associated lipocalin concentration in healthy newborns during the first three postnatal days
}

\author{
Vinka Mikulić*1 , Dunja Rogić , Ivanka Mikulićㅁ, Kristina Ljubić1, Ana Cuk1, Vajdana Tomić3 , Helena Radić Mišković4 \\ ${ }^{1}$ Department of Laboratory Diagnostics, University Clinical Hospital Mostar, Mostar, Bosnia and Herzegovina \\ 2Department of Laboratory Diagnostics, University Hospital Center Zagreb, Zagreb, Croatia \\ ${ }^{3}$ Department of Obstetrics and Gynaecology, University Clinical Hospital Mostar, Mostar, Bosnia and Herzegovina \\ ${ }^{4}$ Department of Neonatology, University Clinical Hospital Mostar, Mostar, Bosnia and Herzegovina \\ *Corresponding author: barac.vinka@gmail.com
}

\begin{abstract}
Introduction: Urine neutrophil gelatinase-associated lipocalin (UNGAL) is a biochemical marker significant for early prediction of acute kidney injury in adults. However, it has not been examined sufficiently among the infant population, particularly newborns in terms of reference values. The aim of our study was to determine the concentration of uNGAL in healthy term newborns and to determine if there was a difference in uNGAL concentration according to gender, postnatal age and birth weight.

Materials and methods: Our study involved 81 healthy term newborns birth ( $\geq 37$ weeks, Apgar score $\geq 8$ in the first minute after birth, CRP $<5$ $\mathrm{mg} / \mathrm{L}$ ). Urine NGAL was measured using chemiluminescent microparticle immunoassay (CMIA) within 72 hours after birth, on Architect plus ci8200 analyser (Abbott, Chicago, USA). Data were analysed using Statistica software.

Results: The median concentration of uNGAL in the whole study group of healthy term newborns was $27.1 \mathrm{ng} / \mathrm{mL}(16.5-56.0 \mathrm{ng} / \mathrm{mL}$ ) (newborn girls, $27.1 \mathrm{ng} / \mathrm{mL}$ (15.8-47.9 ng/mL); newborn boys, $27.9 \mathrm{ng} / \mathrm{mL}(16.5-61.0 \mathrm{ng} / \mathrm{mL}), \mathrm{P}=0.941)$. Median uNGAL concentration according to postnatal age expressed in days was $28.2 \mathrm{ng} / \mathrm{mL}(11.7-57.2 \mathrm{ng} / \mathrm{mL}))^{\text {st }}$ day, $28.9 \mathrm{ng} / \mathrm{mL}(16.5-64.2 \mathrm{ng} / \mathrm{mL}) 2^{\text {nd }}$ day and $23.9 \mathrm{ng} / \mathrm{mL}(20.2-46.6) 3^{\text {rd }}$ day, $P=0.863$. Regarding birth weight for newborns $<3500 \mathrm{~g}$, median concentration was $25.0 \mathrm{ng} / \mathrm{mL}(16.5-45.4 \mathrm{ng} / \mathrm{mL})$ and for weight $\geq 3500 \mathrm{~g} 30.6 \mathrm{ng} / \mathrm{mL}$ (16.5-64.2 $\mathrm{ng} / \mathrm{mL}), \mathrm{P}=0.455$.
\end{abstract}

Conclusions: There were no significant difference in UNGAL concentration in relation to gender, postnatal age and birth weight.

Keywords: neutrophil gelatinase-associated lipocalin; urine; healthy term newborns

\section{Introduction}

Neutrophil gelatinase-associated lipocalin (NGAL), also known as lipocalin-2, LCN2, siderocalin, 24p3, is a $25 \mathrm{kDa}$ molecular weight protein. It belongs to the lipocalin superfamily, which consists of proteins that transport small hydrophobic molecules such as lipids, steroid hormones and retinoids (1). This biochemical marker appears to be significant in early detection of acute kidney injury, but currently it has not been sufficiently examined in the paediatric population, particularly in newborns population. Although NGAL can be secreted by different types of cells, some research data indicate its high diagnostic sensitivity and specificity in acute kidney injury. Numerous studies emphasise its predictive, diagnostic and prognostic benefits in acute kidney injury (2-8). To date, research on urine NGAL in newborn population has included certain conditions and illnesses such as asphyxia and sepsis, which might cause acute kidney injury. In most research, reference groups consisted 
of a small number of healthy newborns (9-12). There is not enough data about NGAL concentration in healthy infants, including both serum and urine NGAL, which challenges the probability of correct interpretation in different pathological conditions. Thus, the aim of the study was to determine the concentration of urine NGAL (UNGAL) in healthy term newborns, as well as to determine if there was a difference between urine NGAL concentration in relation to gender, postnatal age and birth weight. The hypothesis was that UNGAL concentration does not depend on gender, postnatal age and birth weight.

\section{Materials and methods}

\section{Subjects}

The present study was prospective and included 81 healthy newborn (newborns girls, $\mathrm{N}=31$ and newborn boys, $\mathrm{N}=50$ ) born at University Hospital Mostar, Bosnia and Herzegovina, from April to October 2019. The study was approved by the Ethics Committee of the University Clinical Hospital Mostar (Ethical approving number 2272/12 at UCHM) in adherence to the Declaration of Helsinki. Written informed consent was obtained from all parents after explaining the purpose of the study. The newborns included in the study were delivered from full-term pregnancies and inclusion criteria after clinical examination were as follows: gestational age at birth $\geq 37$ weeks, Apgar score $\geq 8$ in the first minute after birth, $C$-reactive protein (CRP) $<5 \mathrm{mg} / \mathrm{L}$, normal physical and ultrasound examination (12-14). If routine clinical examination after birth showed the presence of infection, cardiac disease, congenital anomalies and chromosomal disorder, the newborns were excluded from the study.

\section{Methods}

The present study used the leftover serum samples that had previously been analysed in routine laboratory tests (mainly bilirubin) required by a neonatologist after the post-delivery examination. The leftover serum was used to determine CRP concentration, which was the including criteria for the study. Venous blood samples were collected in Micro sample tubes with gel (Sarstedt, Nümbrecht, Germany; volume $1.1 \mathrm{~mL}$ ) with Micro needles 23 G (Sarstedt, Nümbrecht, Germany). CRP concentration was determined using a CRP Latex reagent kit (Beckman Coulter, Co. Clare, Ireland) on Beckman Coulter Chemistry Analyser AU680 (Beckman Coulter, Brea, USA), controlled two times a day (ITA Control Serum Level 1, REF. ODC0014; ITA Control Serum Level 2, REF.ODC0015; ITA Control Serum Level 3, REF.ODC0016). Urine samples (3 $-5 \mathrm{~mL}$ ) were obtained within 72 hours after birth in paediatric urine sterile collector for newborns with a birth weight over $2000 \mathrm{~g}$ (B. Braun Medical, Saint-Cloud, France) and centrifuged at 400 RCF over five minutes and stored at $-80^{\circ} \mathrm{C}$ until analysis. Urine NGAL concentration was quantitatively determined using original manufacturer Architect Urine NGAL reagent kit (REF.1P37, LOT.89159UI00, Abbott, Sligo, Ireland) on Architect plus ci8200 analyser (Abbott, Chicago, USA). The Architect Urine NGAL assay is a two-step immunoassay for the quantitative detection of NGAL in human urine using chemiluminescent microparticle immunoassay (CMIA) technology. The Architect urine NGAL assay utilizes a non-competitive, sandwich format with chemiluminescent signal detection. The assay includes a microparticle reagent prepared by covalently attaching an anti-NGAL antibody to paramagnetic particles and a conjugate reagent prepared by labelling a second anti-NGAL antibody with acridinium. Following the immunochemistry steps, the solid phase is washed again and the acridinium label is triggered with peroxide and base to generate the signal (15). The assay was calibrated according to the manufacturer's instructions (Architect Urine NGAL Calibrators, Abbott, Ireland REF.1P37-01, LOT.86303UI00, $0.0 \mathrm{ng} / \mathrm{mL}$, $10.0 \mathrm{ng} / \mathrm{mL}, 100.0 \mathrm{ng} / \mathrm{mL}, 500.0 \mathrm{ng} / \mathrm{mL}, 1000.0 \mathrm{ng} /$ $\mathrm{mL}, 1500.0 \mathrm{ng} / \mathrm{mL}$ ) and checked by using commercial controls (Architect Urine NGAL Controls, Abbott, Ireland, REF.1P37-10, LOT.90414UI00, Low Control $20.0 \mathrm{ng} / \mathrm{mL}$, Medium Control $200.0 \mathrm{ng} / \mathrm{mL}$, High Control $1200.0 \mathrm{ng} / \mathrm{mL}$ ). According to Architect Urine NGAL manufacturer's study, which was based on Laboratory Standards Institute (CLSI) EP15-A2 guidance, CV was $\leq 6.7 \%$. 
TABLE 1. General characteristics of healthy newborns

\begin{tabular}{lccc}
\hline Characteristic & $\mathbf{F}(\mathbf{N}=\mathbf{3 1})$ & $\mathbf{M}(\mathbf{N}=\mathbf{5 0})$ & P value $^{*}$ \\
\hline $\begin{array}{l}\text { Gestation age } \\
\text { (weeks) }\end{array}$ & $39.4(37.0-41.1)$ & $39.6(37.0-41.4)$ & 0.872 \\
\hline Birth weight $(\mathrm{g})$ & $3350(2950-3600)$ & $3525(3250-3800)$ & 0.056 \\
\hline Birth length $(\mathrm{cm})$ & $54(53-56)$ & $55(53-56)$ & 0.134 \\
\hline Apgar score $(1 \mathrm{~min})$ & $10(10-10)$ & $10(10-10)$ & 0.741 \\
\hline
\end{tabular}

Data are presented as the median and interquartile range, except for gestation age that is presented as median and minimum maximum. *Mann-Whitney U-test. $\mathrm{F}$ - newborn girls. $\mathrm{M}$ - newborn boys. $\mathrm{P}<0.05$ was considered statistically significant.

\section{Statistical analysis}

Data analysis was performed using Statistica 12.0. software (StatSoft, Tulsa, OK, USA). Non-parametric tests were used because the obtained data were not normally distributed (Shapiro Wilk test). Measurement data were indicated as median and interquartile range (from first (Q1) to the third quartile (Q3)), except for gestation age that is presented as median and minimum - maximum. To compare two groups, Mann-Whitney U-test was used. Kruskal-Wallis test was used to compare more groups. P values $<0.05$ were considered statistically significant.

\section{Results}

The study comprised 81 healthy term neonates, newborn girls (subgroup F) and newborn boys (subgroup M). The respective median gestational ages were 39 (37-41) weeks in females, and 40 (3741) weeks in males. Median values with an interquartile range along with general characteristics of healthy newborns (birth weight, birth length and Apgar score) differentiated by gender are shown in Table 1. No parameter was shown to be statistically significantly different between genders, although we observed an almost significant difference regarding birth weight $(P=0.056)$. Median UNGAL concentration in the whole study group was $27.1 \mathrm{ng} / \mathrm{mL}$ (16.5-56.0 ng/mL). The values did not differ between genders $(P=0.941)$, in relation to postnatal age $(P=0.863)$ nor in relation to birth weight $(P=0.455)$ (Table 2$)$.
TABLE 2. Urine neutrophil gelatinase-associated lipocalin (uN$G A L)$ concentration of healthy newborns

\begin{tabular}{llc}
\hline Parameter & uNGAL $(\mathbf{n g} / \mathbf{m L})$ & P \\
\hline Total group $(\mathrm{N}=81)$ & $27.1(16.5-56.0)$ & $/$ \\
\hline Gender & & \\
$\mathrm{F}(\mathrm{N}=31)$ & $27.1(15.8-47.9)$ & $0.941^{*}$ \\
$\mathrm{M}(\mathrm{N}=50)$ & $27.9(16.5-61.0)$ & \\
\hline Postnatal age & & \\
1st day $(\mathrm{N}=20)$ & $28.2(11.7-57.2)$ & \\
2nd day $(\mathrm{N}=51)$ & $28.9(16.5-64.2)$ & $0.863^{\dagger}$ \\
3rd day $(\mathrm{N}=10)$ & $23.9(20.2-46.6)$ & \\
\hline Birth weight & \\
$<3500 \mathrm{~g}(\mathrm{~N}=41)$ & $25.0(16.5-45.4)$ & $0.455^{*}$ \\
$\geq 3500 \mathrm{~g}(\mathrm{~N}=40)$ & $30.6(16.5-64.2)$ & \\
\hline
\end{tabular}

Data are presented as the median and interquartile range. ${ }^{*}$ Mann-Whitney U-test. ${ }^{\dagger}$ Kruskal-Wallis test. $\mathrm{P}<0.05$ was considered statistically significant.

\section{Discussion}

The study demonstrated that there was no significant difference in UNGAL concentration in relation to gender, postnatal age and birth weight, which supports the hypothesis mentioned beforehand. There have been several studies that included uNGAL concentration measurement in a healthy newborn population. One of these studies, done by Chen et al., included measurement of UNGAL in 38 term newborns when they were three days old. The median concentration of UNGAL was $88.1 \mathrm{ng} /$ 
$\mathrm{mL}$ (16). The uNGAL values were higher than in our study. Another study by Sarafidis et al. was carried out on 22 term infants on their first and third day of life. Median urine NGAL concentration on the first day of a newborns life was $6.8 \mathrm{ng} / \mathrm{mL}$, while this concentration was $7.1 \mathrm{ng} / \mathrm{mL}$ on the third day (17). Abdelhady et al. carried out a research on a control group of 20 newborns and results showed the median UNGAL concentration of $9 \mathrm{ng} / \mathrm{mL}$ (18). The only research carried out on a higher number of subjects was conducted by Kamianowska et al. (19). This research included 88 term-neonates with median uNGAL concentration of $16.74 \mathrm{ng} / \mathrm{mL}$. In contrast to our study, their study proved that uNGAL concentration is significantly higher in female newborns. The median concentration of UNGAL was $24.16 \mathrm{ng} / \mathrm{mL}$ for female neonates and 13.30 $\mathrm{ng} / \mathrm{mL}$ for male neonates, $\mathrm{P}<0.01$. The $\mathrm{UNGAL}$ values in these studies were lower than those obtained by us (17-19). The reasons for the reported differences may result from different measurement methods, different manufacture reagents and antibodies. Study by Krzeminska et al. on 30 healthy adults demonstrated that UNGAL concentration obtained by CMIA (Abbott) method was significantly higher than ELISA (R\&D Systems) (20). It is highly important to note that the concentrations in the present study were measured using a fully standardized and automated CMIA method, as opposed to most above-mentioned studies using ELISA method from different manufacturers (16-19). Similar results to the present study were published by Cangemi et al. on 25 newborns and the median concentration of UNGAL was $30.3 \mathrm{ng} /$ $\mathrm{mL}$ (CMIA method, Abbott). Also in their study, there wasn't a significant difference regarding uNGAL value associated with gender (21). Early research, which examined a possible correlation between UNGAL, birth weight and postnatal age had obtained conflicting results. Two separate studies, done by Suchojad et al. and Lavery et al., showed a negative correlation between UNGAL and birth weight $(22,23)$. On the contrary, our results are in concordance with Elmas et al. that showed no differences in UNGAL concentrations in regard to birth weight (24). The study Seaidi et al. showed that postnatal age is associated with UNGAL concentration (25). On the other hand, our results agree with Lavery et al. study that showed no differences in UNGAL concentration regarding postnatal age (23). There is a relatively small number of studies that deal with uNGAL concentration measurement in healthy children, especially in newborns within the first days of life. Moreover, other published papers addressing UNGAL concentration measurement include small groups of subjects or children of different ages. Based on the literature review, the present study is the first one that used automated CMIA method for measurement of urine NGAL concentration over 80 healthy term neonates. The big advantage of CMIA method is the shorter time of measurement of UNGAL (in our case about 35 minutes) which is highly important for routine clinical use, and is less demanding in technical manner. Our findings pointed towards a usable reference range limits for UNGAL among the newborn population. However, similar to all previous studies, our study had the same potential limitation - we did not use uNGAL/creatinine ratio. Our rationale was that at this early stage of life creatinine excretion is not constant and therefore cannot be used to improve the variability of the results due to urine concentration. In conclusion, since it was carried out in healthy newborns, as expected, the present study showed no significant difference in concentration of UNGAL in relation to gender, postnatal age and birth weight of new-borns. Future studies should include a higher number of neonates utilizing the same standardized method in order to precisely determine NGAL reference interval for neonate population and thus contribute to the possibility of early acute kidney injury recognition in the first days of life.

\section{Acknowledgments}

The authors wish to thank all neonatal nurses and laboratory technicians for their assistance in collecting samples.

\section{Potential conflict of interest}

None declared. 


\section{References}

1. Mishra J, Ma Q, Prada A, Mitsnefes M, Zahedi K, Yang J, et al. Identification of neutrophil gelatinase-associated lipocalin as a novel early urinary biomarker for ischemic renal injury. J Am Soc Nephrol 2003;14:2534-43. https://doi. org/10.1097/01.ASN.0000088027.54400.C6

2. Mori K, Nakao K. Neutrophil gelatinase-associated lipocalin as the real-time indicator of active kidney damage. Kidney International. 2007;71:967-70. https://doi.org/10.1038/ sj.ki.5002165

3. Mishra J, Dent C, Tarabishi R, Mitsnefes MM, Ma Q, Kelly C, et al. Neutrophil gelatinase-associated lipocalin (NGAL) as a biomarker for acute renal injury after cardiac surgery. Lancet. 2005;365:1231-8. https://doi.org/10.1016/S01406736(05)74811-X

4. Wagener G, Jan M, Kim M, Mori K, Barasch JM, Sladen RN, Lee TH. Association between increases in urinary neutrophil gelatinase-associated lipocalin and acute renal dysfunction after adult cardiac surgery. Anesthesiology. 2006;105:48591. https://doi.org/10.1097/00000542-200609000-00011

5. Nickolas TL, O'Rourke MJ, Yang J, Sise ME, Canetta PA, Barasch $N$, et al. Sensitivity and specificity of a single emergency department measurement of urinary neutrophil gelatinaseassociated lipocalin for diagnosing acute kidney injury. Ann Intern Med. 2008;148:810-9. https://doi.org/10.7326/00034819-148-11-200806030-00003

6. Bennett M, Dent C, Ma Q, Dastrala S, Grenier F, Workman F, et al. Urine NGAL predicts severity of acute kidney injury after cardiac surgery: a prospective study. Clin J Am Soc Nephrol. 2008;3:665-73. https://doi.org/10.2215/CJN.04010907

7. Wheeler DS, Devarajan P, Ma Q, Harmon K, Monaco M, Cvijanovich N, Wong HR. Serum neutrophil gelatinase-associated lipocalin (NGAL) as a marker of acute kidney injury in critically ill children with septic shock. Crit Care Med. 2008;36:1297-303. https://doi.org/10.1097/ CCM.0b013e318169245a

8. Haase M, Bellomo R, Devarajan P, Schlattmann P, Haase-Fielitz A. NGAL Meta analysis Investigator Group. Accuracy of neutrophil gelatinase-associated lipocalin (NGAL) in diagnosis and prognosis in acute kidney injury: a systematic review and meta-analysis. Am J Kidney Dis. 2009;54:1012-24. https://doi.org/10.1053/j.ajkd.2009.07.020

9. Smertka M, Wroblewska J, Suchojad A, Majcherczyk $M$, Jadamus-Niebroj D, Owsianka-Podlesny $T$, et al. Serum and urinary NGAL in septic newborns. BioMed Res Int. 2014;2014:717318. https://doi.org/10.1155/2014/717318

10. Raggal NE, Khafagy SM, Mahmoud NH, Beltagy SE. Serum neutrophil gelatinase-associated lipocalin as a marker of acute kidney injury in asphyxiated neonates. Indian Pediatr. 2013;50:459-62. https://doi.org/10.1007/s13312-013-0153-6

11. El-Farghali OG, El-Raggal NM, Mahmoud NH, Zaina GA. Serum neutrophil gelatinase-associated lipocalin as a predictor of acute kidney injury in critically ill neonates. Pak J Biol Sci. 2012;15:231-7. https://doi.org/10.3923/ pjbs.2012.231.237

12. Spong CY. Defining "term" pregnancy: recommendations from the Defining "Term" Pregnancy Workgroup. JAMA. 2013;309:2445-6. https://doi.org/10.1001/jama.2013.6235
13. Pregnancy, childbirth, postpartum and newborn care: a gu ide for essential practice - 3rd ed. World Health Organization 2015.

14. Adeli K, Higgins V, Trajcevski K, White-Al Habeeb N. The Canadian laboratory initiative on pediatric reference intervals: a CALIPER white paper. Crit Rev Clin Lab Sci. 2017;54:358413. https://doi.org/10.1080/10408363.2017.1379945

15. Grenier FC, Ali S, Syed H, Workman R, Martens F, Liao M, et al. Evaluation of the ARCHITECT urine NGAL assay: assay performance, specimen handling requirements and biological variability. Clin Biochem. 2010;43:615-20. https://doi. org/10.1016/j.clinbiochem.2009.12.008

16. Chen CN, Chou CH, Jeng SF, Tsai IJ, Chen PC, Chen CY, et al. Urinary neutrophil gelatinase-associated lipocalin levels in neonates. Pediatr Neonatol. 2016;57:207-12. https://doi. org/10.1016/j.pedneo.2015.09.003

17. Sarafidis K, Tsepkentzi E, Agakidou E, Diamanti E, Taparkou A, Soubasi $V$, et al. Serum and urine acute kidney injury biomarkers in asphyxiated neonates. Pediatr Nephrol. 2012;27:157582. https://doi.org/10.1007/s00467-012-2162-4

18. Abdelhady S, Abdel Gawad ER, Abdel Haie OM, Mansour Al. Usefulness of serum and urinary neutrophil gelatinase-associated lipocalin in detecting acute kidney injury in asphyxiated neonates. Int J Med Health Sci. 2016;5:230-6.

19. Kamianowska M, Wasilewska A, Szczepanski M, Kulikowska E, Bebko B, Koput A. Health term-born girls had higher levels of urine neutrophil gelatinase-associated lipocalin than boys during the first postnatal days. Acta Paediatr. 2016;105:1105-8. https://doi.org/10.1111/apa.13508

20. Krzeminska E, Wyczalkowska-Tomasik A, Korytowska N, Paczek L. Comparison of Two Methods for Determination of NGAL Levels in Urine: ELISA and CMIA. J Clin Lab Anal. 2016;30:956-60. https://doi.org/10.1002/jcla.21962

21. Cangemi $G$, Storti $S$, Cantinotti $M$, Fortunato $A$, Emdin $M$, Bruschettini $M$, et al. Reference values for urinary neutrophil gelatinase-associated lipocalin (NGAL) in pediatric age measured with a fully automated chemiluminescent platform. Clin Chem Lab Med. 2013;51:1101-5. https://doi. org/10.1515/cclm-2012-0540

22. Suchojad A, Tarko A., Smertka M, Majcherczyk M, Brzozowska A, Wroblewska J, Maruniak-Chudek I. Factors limiting usefulness of serum and urinary NGAL as a marker of acute kidney injury in preterm newborns. Renal Failure. 2015;37:439-45. https://doi.org/10.3109/088602 2X.2014.996109.

23. Lavery AP, Meinzen-Derr JK, Anderson E, Ma Q, Bennett $M R$, Devarajan $P$, et al. Urinary NGAL in premature infants. Pediatr Res. 2008;64:423-8. https://doi.org/10.1203/ PDR.0b013e318181b3b2

24. Elmas AT, Tabel Y, Ipek S. Determination of reference values for urinary neutrophil gelatinase-associated lipocalin in premature infants. J Matern Fetal Neonatal Med. 2014;27:18791. https://doi.org/10.3109/14767058.2013.806900

25. Saeidi B, Koralkar R, Griffin RL, Halloran B, Ambalavanan $N$ Askenazi DJ. Impact of gestational age, sex and postnatal age on urine biomarkers in premature neonates. Pediatric Nephrol. 2015;30:2037-44. https://doi.org/10.1007/s00467015-3129-z 